\title{
Detection of Listeria species, factors associated, and antibiogram of Listeria monocytogenes in beef at abattoirs, butchers, and restaurants of Ambo and Holeta Towns, Ethiopia
}

Endrias Zewdu Gebremedhin ( $\square$ endrias.zewdu@gmail.com )

Ambo University https://orcid.org/0000-0002-9432-6532

Gadisa Hirpa

West Shewa, Ambo district

Bizunesh Mideksa Borana

Ambo University

Edilu Jorga Sarba

Ambo University

Lencho Megersa Marami

Ambo University

Nega Desalegn Tadese

Ambo University

Hirut Abebe Ambecha

Ambo University

Research

Keywords: Antibiogram, Meat, Listeria species, Occurrence, Risk factors, Ethiopia

Posted Date: May 15th, 2020

DOl: https://doi.org/10.21203/rs.3.rs-27928/v1

License: (c) (1) This work is licensed under a Creative Commons Attribution 4.0 International License.

Read Full License 


\section{Abstract \\ Background}

Listeriosis is one of the globally distributed foodborne diseases with the highest fatality rate. Few studies were done on the occurrence of Listeria species from meat at abattoirs, butchers, and restaurants in Ethiopia, and there has been no study conducted at Ambo and Holeta town. The objectives of this study were to isolate and identify Listeria species, assess factors for contamination of meat, and antibiogram of Listeria monocytogenes along the meat chain in Ambo and Holeta towns, Central Ethiopia.

\section{Methods}

450 meat samples were collected from abattoirs $(n=150)$, butchers $(n=150)$ and restaurants $(n=150)$ for isolation and identification of Listeria species using primary culture and biochemical tests. A questionnaire survey and observational checklist were made to assess the potential risk factors for the occurrence of Listeria species such as factors related to socio-demographic characteristics, knowledge on hygiene and practice of food handlers. Pearson's Chi-square and logistic regression analyses were used to assess factors contributing for contamination of meat with Listeria species. Kirby Bauer disc diffusion technique was applied to determine the antimicrobial susceptibility profile of Listeria monocytogenes isolates.

\section{Results}

The overall occurrence of Listeria species in both Ambo and Holeta towns was 28.44\% (128/450; $95 \%$ confidence interval [Cl]: 24.32-32.86\%). The occurrence of L. monocytogenes was 4.4\% (20/450; $95 \% \mathrm{Cl}$ : 2.74-6.78\%), L. ivanovii 2.2\% (10/450; 95\% Cl: 1.07-4.04\%), L. seeligeri 1.78\% (8/450; 95\% Cl: 0.8$3.47 \%)$, L. welshimeri 3.77\% (17/450; 95\% Cl: 2.22-5.98\%), L. inoccua 6.22\% (28/450; 95\% Cl: 4.17$8.87 \%$ ) and $L$. grayi $10.22 \%$ (46/450; $95 \% \mathrm{Cl}: 7.58-13.39 \%)$. The probability of contamination of meat in butchers and restaurants by the Listeria species were comparatively higher in high altitude (Holeta) than medium altitudes (Ambo) [OR $=4.91 ; 95 \% \mathrm{Cl}: 2.65-9.07 \% ; \mathrm{p}<0.001]$, in dry than wet season [OR $=8.78$; $95 \% \mathrm{Cl}: 2.66-28.99 \% ; p<0.001]$ and in butchers and restaurant where the employees work $\geq 9$ hours per day than those working $\leq 8$ hours per day (OR $=3.57 ; 95 \% \mathrm{Cl}: 1.74-7.36 \% ; \mathrm{p}<0.001]$. Of the 20 Listeria monocytogenes isolates, 16 (80\%) were resistant to oxacillin; 14 (70\%) were resistant to amikacin and nalidixic acid; 12 (60\%) were resistant to chloramphenicol and 11 (55\%) were resistant to tetracycline. The L. monocytogenes isolates were $95 \%, 90 \%$ and $85 \%$ susceptible to amoxicillin, vancomycin, and clindamycin, respectively. All (100\%) Listeria monocytogenes isolates were resistant for two or more drugs. Nineteen (95\%) L. monocytogenes isolates were multidrug-resistant. One isolate (5\%) had developed resistance to 10 classes of antimicrobial drugs. 


\section{Conclusions}

Listeria species are widespread in the study areas. The study towns, season and working hours per day are independent predictors of Listeria species isolation. Multidrug resistance among $L$. monocytogenes is common. Therefore, regular training for meat handlers, prudent use of drugs, and further serological and molecular studies on Listeria species are important.

\section{Introduction}

Foodborne bacterial infections describes the adverse health effect associated with eating of contaminated foods with pathogenic bacteria, including those originated from meat and that result either in morbidity or mortality worldwide in general and in developing countries in particular [1]. Meat is the most valuable food of animal origin and its chemical composition makes it one of the most vulnerable vehicles of infections agents [2]. Even though the association of the raw meat consumption habits with health impact over several years has little attention, consumption of raw meat in Ethiopia is deep-rooted tradition [3-5]. Consumption of raw meat contaminated with pathogenic Listeria species causes foodborne listeriosis $[3,4,6]$. Foodborne listeriosis is one of the important diseases affecting human health globally related to the increasing global trade and travel $[4,7,8]$. Thus, even though foodborne listeriosis may be comparatively rare, it causes severe and life-threatening infection in immunocompromised groups such as HIV patients, pregnant women, neonates and elderly [9].

Based on the phenotypic and genotypic characteristic similarities and differences, Listeria species are grouped in to 'Listeria sensu lato' and 'Listeria sensu strictu'[10,11]. Listeria sensu strictu is composed of L. monocytogenes, L.inoccua, L. seelgerii, L.welshimeri and L. marthi. All Listeria sensu strictu are catalase-positive, motile at least at $30^{\circ} \mathrm{C}$ and grow below at $4^{\circ} \mathrm{C}$ and gram-positive. Listeria sensu lato is composed of 11 species comprising $L$. grayi as well as $L$. fleischmannii, L. floridensis, L. aquatica, $L$. newyorkensis, L. cornellensis, L. rocourtiae, L. weihenstephanensis, L. grandensis, L. riparia and L. booriae [12]. Listeria monocytogenes causes foodborne disease and consequently, a serious health problem, because of severe symptoms and high mortality. Nowadays, other species of Listeria are also known to produce a disease in humans and animals [13].

Risk factors of food contamination are defined to be all the factors necessary for food contamination / foodborne outbreaks, infections [14]. Contamination of meat by microorganisms occurs in abattoir during slaughtering and spread from the intestinal tract and the exterior part of animals. Moreover, it can be contaminated in retailer shop and kitchen from air, workers, knives, cloths, carts, and refrigerators [15]. Poor food handling and sanitation practices, inadequate food safety laws, weak regulatory systems, lack of financial resources, improper storage, poor personal hygiene during preparation, extended shelf-lives refrigeration, inadequate cooling and reheating create a favorable condition for the spread of foodborne etiologic agents $[7,16,17]$. Sociodemographic factors, worker's food safety and hygiene information, knowledge on food safety and hygiene, food safety principles and practices, food source and others are 
few of the food contamination predictors [14]. The increased use of antimicrobial agents in food animal production and human is a significant factor in the emergence of antimicrobial resistant bacteria

The repetitive use of antimicrobials in food animal production for treatment and as growth promotion is significant factor for the emergence of multi drugs resistant strains $[4,8]$. Meat is a major source of transmission of antimicrobial resistant microorganisms to humans [18]. As a result, control and treatment of listeriosis is difficult and very hazardous without antimicrobial resistance interventions [19]

There have been few studies conducted on the occurrence of Listeria species in food samples including meat sources like poultry, mutton, pork, seafood and other foods of animal origins in Ethiopia $[3,4,7,20$, 21]. However, the occurrence, risk factors and antibiogram of Listeria species along the consecutive meat chain from abattoirs, butchers and restaurants have not been studied so far. Careful investigation of raw meat samples collected from the three spots of the beef chain (abattoir, butcher, and restaurant) will help to identify the weak links contributing to the contamination. This helps considerably for subsequent interventions in an attempts to protect consumers from foodborne illnesses and to reduce economic losses due to food spoilage. Therefore, the objectives of the present study were to isolate and identify Listeria specie, assess factors contributing for contamination of beef and determine the antibiogram of Listeria monocytogenes isolated from abattoir, butchers and restaurant in Ambo and Holeta towns, central Ethiopia.

\section{Materials And Methods}

\section{Study area}

The study was conducted in Ambo and Holeta towns found in Oromia Region, central Ethiopia. Ambo town is the administrative center of West Shoa Zone located $114 \mathrm{~km}$ West of Addis Ababa at the latitude of $8^{\circ} 59^{\prime} \mathrm{N} 37^{\circ} 51^{\prime} \mathrm{E}$ and longitude of $8.983^{\circ} \mathrm{N} 37.85^{\circ} \mathrm{E}$. The elevation of Ambo town ranges from 1900 to 2275 meters above sea level (masl). Its temperature ranges from $19{ }^{\circ} \mathrm{C}$ to $29^{\circ} \mathrm{C}$ with an average annual temperature of $22^{\circ} \mathrm{C}$ and an average annual rainfall of about $900 \mathrm{~mm}$. The town has a total human population of 74,843 out of which 39,192 are males and 35,651 are females [22]. There are 46 legal butchers with their annexed restaurants and one municipality abattoir in Ambo town.

Holeta is located in Finfine special zone, $44 \mathrm{~km}$ West of Addis Ababa with latitude and longitude of $9^{\circ} 3^{\prime} \mathrm{N} 38^{\circ} 30^{\prime} \mathrm{E} / 9.050^{\prime} \mathrm{N} 38.500^{\circ} \mathrm{E}$. Its elevation is 2400 masl. It receives $1144 \mathrm{~mm}$ annual average precipitation, with an average minimum and maximum temperature of $6^{\circ} \mathrm{C}$ and $22^{\circ} \mathrm{C}$, respectively. The total human population of Holeta town is 25,593 , of whom 12,605 are men and 12,988 women [22]. There are 20 legal butchers with annexed restaurants and one municipality abattoir in Holeta town.

\section{Study Population}


All abattoirs, butchers, restaurants in Ambo and Holeta towns constituted the targets of this study. Cattle slaughtered in Ambo and Holeta abattoirs and beef sold in butcher shops and restaurants of Ambo and Holeta towns are the study population.

\section{Study Design}

The study was conducted between October 2017 to April 2018 in abattoirs, butchers and restaurants of Ambo and Holeta towns.

First, the list of all the current legal butchers, restaurants and abattoirs registered in Ambo and Holeta towns was collected from the towns' municipality (sampling frame) and then the two abattoirs (one from each town) and those butchers with annexed restaurant for handling meat were purposively identified.

\section{Sample Size Determination}

The required sample size was determined using a 95\% confidence limit and a $7 \%$ sampling error and an expected prevalence of $25 \%$ [4] by the following formula [23].

$$
\mathrm{n}=\frac{1.96^{2} X \operatorname{Pexp}(1-\text { Pexp })}{\mathrm{d}^{2}}
$$

Where $\mathrm{n}=$ sample size

Pexp $=$ Expected prevalence

$d=$ Desired absolute precision

Thus, a sample size of 147 was calculated. Thus a total of 450 meat samples consisting of 150 from abattoirs, 150 from butchers and 150 from restaurants were sampled. For the 20 butchers of Holeta town, 87 samples were assigned (every 29 samples from abattoir, butchers, and restaurants), while the corresponding values for one abattoir, butchers and restaurants (each 46) in Ambo town was 363 (121 samples from each establishment).

\section{Sample collection}

Systematic random sampling method was used to select the animals from study population. Following slaughtering, meat samples were collected from three spots of the beef chain (abattoir, butcher, and restaurant) from the same animal. First composite meat samples of about $250 \mathrm{gm}$ were collected from slaughtered cattle from four sites (ramp, flank, brisket, and neck) just after the stage of evisceration. The 
same procedure was followed on the second sampling spot, i.e. butcher shops. On the third sampling spot, $250 \mathrm{~g}$ raw meat that is prepared to be served for consumption (Kitfo-a traditional Ethiopian dish made from minced raw beef, chili, spice and butter blend or Tire sega-special meat cut served raw) was purchased. All samples were collected aseptically, and the samples were labeled with necessary information including the sample code, date of sampling and sampling place (spot). Samples were kept in separate sterile plastic bags (Seward, England), to prevent spilling and cross-contamination and immediately transported to the Ambo University Veterinary Microbiology Laboratory in a cooler icebox with ice packs and processed within $4 \mathrm{hrs}$.

\section{Isolation and identification of Listeria species}

As per the recommendation of ISO [24], $25 \mathrm{~g}$ of sample was homogenized in $225 \mathrm{ml}$ of Listeria enrichment broth (LEB) containing supplements (HiMedia, India) using a laboratory blender and incubated at $30^{\circ} \mathrm{C}$ for $24 \mathrm{hrs}$. Then after $0.1 \mathrm{ml}$ of mixed inoculum was inoculated into a tube containing $10 \mathrm{ml}$ Modified Fraser broth (MFB) and incubated for $24 \mathrm{hrs}$ at $37^{\circ} \mathrm{C}$. Following enrichment procedure, the inoculum was streaked on Oxford agar (OXA) containing manufacturer's supplements and the plates were incubated at $37^{\circ} \mathrm{C}$ for $24-48 \mathrm{hrs}$. After $24 \mathrm{hrs}$ of incubation, the growth of Listeria species on the Oxford agar plate was examined for black halo colonies of Listeria species, which remain the same after $48 \mathrm{hrs}$ of incubation but with a sunken center.

The presumptive colonies were picked up and further purified on Tryptone Soya Yeast Extract agar (TSYEA). Subsequently, pinpoint colonies on TSYEA were subjected to identification procedures, which included Gram's staining followed by a microscopic examination, catalase test, and oxidase test. The characteristic Gram-positive, coccobacillus or short rod-shaped organisms, which were catalase-positive and oxidase negative, were sub-cultured in Brain heart infusion (BHI) broth at $25^{\circ} \mathrm{C}$ for $12-18 \mathrm{hrs}$. Subsequently, the cultures showing typical tumbling motility were considered as "presumptive" Listeria isolates, which were in turn subjected to detailed biochemical tests viz.; CAMP test, methyl red, VogesProskauer, and sugar fermentation tests with xylose, rhamnose, and mannitol for identification of Listeria to species level.

\section{Questionnaire Survey}

A semi-structured pretested questionnaire survey and observational checklist were used on abattoir personnel, butcher shop workers and restaurant chefs and waiters to assess their hygienic practice in processing and handling beef and beef products along the chain. The independent factors investigated along with their categories include: sex (male vs. female), marital status (single vs. married), the residence of origin (rural vs. urban), educational status (uneducated, primary school, secondary school, and tertiary), time on work per day ( $\leq 8$ hours vs. $\geq 9$ hours), information on food hygiene, training on food safety, use of refrigeration, presence of insects and presence of rodents (all yes or. no), sanitation of 
butchers and restaurants, hygiene of the slicing materials, hygiene of the cutting boards, hygiene of the weighing balance and food handling surfaces (all categorized as poor, fair, good, and very good).

\section{Antimicrobial Susceptibility Test}

The L. monocytogenes isolates were subjected to antimicrobial susceptibility test against 16 commercially available antimicrobial disks selected based on common usage. The antimicrobial disc selected were amikacin $(30 \mu \mathrm{g})$, amoxicillin $(10 \mu \mathrm{g})$, ampicillin $(10 \mu \mathrm{g})$, chloramphenicol $(30 \mu \mathrm{g})$, cefotaxime $(30 \mu \mathrm{g})$, gentamicin $(10 \mu \mathrm{g})$, tetracycline $(30 \mu \mathrm{g})$, oxacillin $(1 \mu \mathrm{g})$, vancomycin $(10 \mu \mathrm{g})$, cotrimoxazole $(25 \mu \mathrm{g})$, nalidixic acid $(30 \mu \mathrm{g})$, ciprofloxacin $(5 \mu \mathrm{g})$, erythromycin $(15 \mu \mathrm{g})$, clindamycin $(2 \mu \mathrm{g})$, penicillin $(6 \mu \mathrm{g})$, and trimethoprim-sulfamethoxazole $(23.75 \mu \mathrm{g})$. Antimicrobial susceptibility test was conducted using the disk diffusion method following guidelines established by the Clinical and Laboratory Standards Institute CLSI [25]. Two to three pure fresh colonies of the isolates from TSAYE were used to prepare cell suspension in to the Muller Hilton broth (HiMedia, India) and incubated for 24 hrs at $37^{\circ} \mathrm{C}$. Following this, the cell suspension turbidity was attuned to equal $0.5 \mathrm{McF}$ arland Standard. Then, a sterile cotton swab was used to spread the bacterial suspension on the Muller Hinton agar (HiMedia, India). According to the standard procedure CLSI [25], the disks were firmly placed in the interval of $3 \mathrm{~cm}$ spacing from each other onto the medium with sterile forceps and then incubated at 37 ${ }^{\circ} \mathrm{C}$ for $24 \mathrm{hrs}$. Then, the diameter of clear zones around the disks was measured with a ruler against black background and compared with standards given by CLSI [25]. L. monocytogenes ATCC7644, E. coli ATCC25922, and S. aureus ATCC6538 reference strains were used as quality control.

\section{Data Management And Analysis}

The collected data were entered into Microsoft Excel spreadsheets (Microsoft Corporation) and analyzed using STATA version 14.2 software (Stata Crop. College Station, USA). Descriptive statistics was utilized to summarize the occurrence, socio demographic characteristics of the respondents and antimicrobial susceptibility data using percentages. Univariable and multivariable logistic regression analyses with their Odd Ratio (OR) and 95\% confidence Intervals (95\% $\mathrm{Cl}$ ) were used to assess the factors associated with contamination of beef by Listeria species. During analysis, for all of the risk factors, the first category of the independent variables (with the lowest percentage) was considered as a reference category. Non-collinear variables were selected with the help of a multicollinearity matrix. Elimination of collinear variable with the poor biological background to explain possible contamination of raw beef by Listeria species was used to handle collinear variables. Non-collinear variables that possessed a $p$-value of $<0.25$ in univariable analysis were entered into the multivariable analysis. The model was constructed by a backward exclusion method. Hosmer-Lemeshow goodness of- fit- test was used to assess the model fitness. The reliability of the fitted model was further evaluated using the receiver operating characteristics curve (ROC). The $95 \%$ confidence interval (Cl) was used in all cases and the results were considered significant at $\mathrm{p}<0.05$. 


\section{Results}

\section{Isolation and identification of Listeria species}

Out of the total 450 meat samples examined, 128 (28.44\%; 95\%: Cl: 24.32-32.86\%) were positive for Listeria species. The occurrence of Listeria species in Ambo town (20.66\%) was much lower when compared to Holeta town (60.92\%). The highest rate of occurrence of Listeria species was recorded in restaurants $(30.00 \%)$, followed by butchers $(29.33 \%)$ and then abattoir $(26.00 \%)$. The occurrence of Listeria species in abattoir and restaurant samples of Holeta town was relatively higher than abattoir and restaurant samples of Ambo town (Table 1).

Table 1

The occurrence of Listeria species isolated from cattle raw meat from abattoirs, butchers and restaurants of Ambo and Holeta towns, Central Ethiopia.

\begin{tabular}{|c|c|c|c|c|c|}
\hline \multirow[t]{2}{*}{ Study towns } & \multirow[t]{2}{*}{ Establishment } & \multirow[t]{2}{*}{ Tested } & \multicolumn{3}{|c|}{ Listeria species } \\
\hline & & & No. positive & \% occurrence & 95\% Cl [Lower-Upper] \\
\hline \multirow[t]{4}{*}{ Ambo } & Abattoir & 121 & 25 & 20.66 & $13.84-28.97$ \\
\hline & Butchers & 121 & 22 & 18.18 & $11.76-26.22$ \\
\hline & Restaurants & 121 & 28 & 23.14 & $15.96-31.68$ \\
\hline & Sub total & 363 & 75 & 20.66 & $16.61-25.20$ \\
\hline \multirow[t]{4}{*}{ Holeta } & Abattoir & 29 & 14 & 48.28 & $29.45-67.47$ \\
\hline & Butchers & 29 & 22 & 75.86 & $56.46-89.70$ \\
\hline & Restaurants & 29 & 17 & 58.62 & $38.94-76.48$ \\
\hline & Sub total & 87 & 53 & 60.92 & $49.87-71.21$ \\
\hline \multirow[t]{3}{*}{ Subtotal } & Abattoirs & 150 & 39 & 26.00 & $19.19-33.79$ \\
\hline & Butchers & 150 & 44 & 29.33 & $22.19-37.31$ \\
\hline & Restaurants & 150 & 45 & 30.00 & $22.80-38.01$ \\
\hline Total & & 450 & 128 & 28.44 & $24.32-32.86$ \\
\hline
\end{tabular}

Out of the total 128 Listeria species isolated, a high contamination rate of Listeria grayi and low contamination rate of Listeria seeligeri were recorded. The overall occurrence of L. monocytogenes was $4.44 \%$ (Table 2). The occurrence of $L$. monocytogenes in abattoirs, butchers, and restaurants raw meat samples of cattle were $33 \%, 1.56 \%$, and $1.56 \%$, respectively. 
Table 2

Listeria species identified from cattle raw meat in Ambo and Holeta towns, Oromia, Central Ethiopia $(n=450)$.

\begin{tabular}{|llll|}
\hline Listeria species & No of positive & \multicolumn{2}{l|}{ Identified Listeria species } \\
\cline { 3 - 4 } & & $\%$ & $95 \%$ Cl [Lower-Upper] \\
\hline Listeria monocytogenes & 20 & 4.44 & $2.74-6.78$ \\
\hline Listeria ivanovii & 10 & 2.22 & $1.07-4.04$ \\
\hline Listeria seeligeri & 8 & 1.78 & $0.80-3.47$ \\
\hline Listeria welshimeri & 17 & 3.78 & $2.22-5.98$ \\
\hline Listeria innocua & 28 & 6.22 & $4.17-8.87$ \\
\hline Listeria grayi & 46 & 10.22 & $7.58-13.39$ \\
\hline Total & 128 & 28.44 & $24.32-32.86$ \\
\hline
\end{tabular}

\section{Risk Factors}

\section{Socio-demographic characteristics, knowledge, and practice on food safety and hygiene}

All respondents from abattoirs and butchers were male while all respondents from restaurants were females. The majority of the respondents from abattoirs (57.58\%) were within the age group of $18-$ 24 years while that of butchers $(58.62 \%)$ and restaurants $(52.41 \%)$ were $\geq 35$ years and $25-34$ years, respectively. The majority of the respondents attended primary education and had less than one year of work experience. Most of the workers in butchers and restaurants work $\geq 9$ hours per day (Table 3 ). 
Table 3

Socio demographic characteristics of workers of abattoirs, butchers, and restaurants of Ambo and Holeta towns.

\begin{tabular}{|c|c|c|c|c|c|c|c|}
\hline \multirow[t]{2}{*}{ Variables } & \multirow[t]{2}{*}{ Categories } & \multicolumn{2}{|c|}{$\begin{array}{l}\text { Abattoirs } \\
\text { Workers }\end{array}$} & \multicolumn{2}{|c|}{$\begin{array}{l}\text { Butcher } \\
\text { Workers }\end{array}$} & \multicolumn{2}{|c|}{$\begin{array}{l}\text { Restaurants } \\
\text { Workers }\end{array}$} \\
\hline & & Freq. & $\%$ & Freq. & $\%$ & Freq. & $\%$ \\
\hline \multirow[t]{2}{*}{ Sex } & Male & 33 & 100 & 145 & 100 & - & - \\
\hline & Female & - & - & - & - & 145 & 100 \\
\hline \multirow[t]{3}{*}{ Age in years } & $18-24$ & 19 & 57.58 & 19 & 13.10 & 5 & 3.45 \\
\hline & $25-34$ & 11 & 33.33 & 41 & 28.28 & 76 & 52.41 \\
\hline & $\geq 35$ & 3 & 9.09 & 85 & 58.62 & 64 & 44.4 \\
\hline \multirow[t]{2}{*}{ Marital status } & Single & 14 & 42.42 & 55 & 37.93 & 77 & 53.1 \\
\hline & Married & 19 & 57.58 & 90 & 62.07 & 68 & 46.9 \\
\hline \multirow[t]{2}{*}{ Residence of origin } & Rural & 26 & 78.79 & 54 & 37.24 & 82 & 56.55 \\
\hline & Urban & 7 & 21.21 & 91 & 67.76 & 63 & 43.45 \\
\hline \multirow[t]{2}{*}{ Religion } & $\begin{array}{l}\text { Protestant and } \\
\text { others }\end{array}$ & 12 & 36.06 & 12 & 8.18 & 53 & 36.55 \\
\hline & Orthodox & 21 & 63.64 & 133 & 91.72 & 92 & 63.45 \\
\hline \multirow[t]{4}{*}{ Education } & Illiterate & 3 & 9.09 & 5 & 3.45 & 18 & 12.41 \\
\hline & Primary school & 17 & 51.52 & 80 & 55.17 & 98 & 67.59 \\
\hline & Secondary school & 6 & 18.18 & 14 & 9.66 & - & - \\
\hline & Tertiary & 7 & 21.21 & 46 & 31.72 & 29 & 20 \\
\hline \multirow{3}{*}{$\begin{array}{l}\text { Work experience in } \\
\text { years }\end{array}$} & $<1$ & - & - & 93 & 64.14 & 73 & 50.34 \\
\hline & $1-3$ & - & - & 19 & 13.10 & 47 & 32.41 \\
\hline & $\geq 4$ & - & - & 33 & 22.76 & 25 & 17.24 \\
\hline \multirow[t]{2}{*}{ Working time per day } & $\leq 8$ hours & 33 & 100 & 33 & 22.76 & 46 & 31.72 \\
\hline & $\geq 9$ hours & - & - & 112 & 77.24 & 99 & 68.28 \\
\hline
\end{tabular}

The vast majority of respondents had information/knowledge on food hygiene and safety, often without practicing it but had no training on food safety (Table 4). 
Table 4

Knowledge and practice on food safety and hygiene of workers of abattoirs, butchers, and restaurants of Ambo and Holeta towns.

\begin{tabular}{|llllllll|}
\hline Factors & Categories & \multicolumn{2}{l}{$\begin{array}{l}\text { Abattoirs } \\
\text { Workers }\end{array}$} & \multicolumn{2}{l}{$\begin{array}{l}\text { Butcher } \\
\text { Workers }\end{array}$} & \multicolumn{3}{l|}{$\begin{array}{l}\text { Restaurants } \\
\text { Workers }\end{array}$} \\
\cline { 2 - 8 } & & Freq. & $\%$ & Freq. & $\%$ & Freq. & $\%$ \\
\hline $\begin{array}{l}\text { Information on food hygiene \& } \\
\text { safety }\end{array}$ & No & 3 & 0.09 & 34 & 23.45 & 20 & 13.7 \\
\cline { 2 - 8 } & Yes & 30 & 90.91 & 111 & 76.55 & 125 & 86.21 \\
\hline Training on food safety & Yes & 5 & 15.15 & 16 & 11.03 & 4 & 2.76 \\
\cline { 2 - 8 } & No & 28 & 84.85 & 129 & 88.97 & 141 & 97.24 \\
\hline $\begin{array}{l}\text { Knowledge of food safety and } \\
\text { hygiene }\end{array}$ & Yes & 22 & 66.67 & 103 & 71.03 & 76 & 52.41 \\
\cline { 2 - 8 } & No & 11 & 33.33 & 42 & 28.97 & 69 & 47.59 \\
\hline The practice of food hygiene & No & 18 & 54.55 & 74 & 51.03 & 48 & 33.1 \\
\cline { 2 - 8 } & Yes & 15 & 45.45 & 71 & 48.97 & 97 & 66.9 \\
\hline Use of refrigeration & No & 33 & 100 & 11 & 7.59 & 15 & 10.34 \\
\cline { 2 - 8 } & Yes & - & - & 134 & 92.41 & 130 & 89.66 \\
\hline Presence of insects & No & 33 & 100 & 41 & 28.28 & 27 & 18.67 \\
\hline Presence of rodents & Yes & & & 104 & 71.72 & 118 & 61.38 \\
\hline & Yes & - & - & 21 & 14.48 & 56 & 38.62 \\
\hline & No & 33 & 100 & 124 & 85.52 & 89 & 61.38 \\
\hline
\end{tabular}

\section{Chi-square Analysis}

Results of Chi-square analysis showed significant association between cattle raw meat contamination by Listeria species and study towns (Chi-square $\left[X^{2}\right]=28.5162, P=<0.001$, season $\left(X^{2}=17.4298, P=<\right.$ $0.001)$, number of hours worked per day $\left(X^{2}=4.4096, P=<0.001\right)$, information on food hygiene and safety $\left(X^{2}=2.4979, P=0.036\right)$, hygiene of the cutting boards $\left(X^{2}=12.0199, P=0.007\right)$ and use of refrigerator $\left(X^{2}=3.9451, P=0.047\right)$. All the other investigated factors were not significantly associated with the isolation rate of Listeria species (data not shown) $(P>0.05)$.

\section{Logistic Regression Analyses}

Univariable logistic regression analysis showed that the raw cattle meat contamination rate by Listeria species was significantly different $(p<0.001)$ between study towns, seasons and working times per day. 
Accordingly the risk of cattle raw meat contamination in Holeta town was 4.91times higher than in Ambo town $(\mathrm{OR}=4.91,95 \% \mathrm{Cl}: 2.65-9.07 ; \mathrm{p}<0.001)$. The risk of of Listeria species contamination in dry season was 8.78 times higher when compared to the risk of contamination in wet season ( $\mathrm{OR}=8.78,95 \% \mathrm{Cl}$ : 2.66-28.99; $P<0.001)$. Similarly, the risk of cattle raw meat contamination was 3.57 times higher in butchers and restaurants where the working hours per day was $\geq 9$ hours as compared to butchers and restaurants where the working hours was $\leq 8$ per day $(\mathrm{OR}=3.57,95 \% \mathrm{Cl}: 1.74-7.36 ; p<0.001)$ ). Univariable logistic regression analysis also showed that the occurrence of Listeria species in meat was significantly associated with the hygiene of cutting boards $(p<0.05)$. All the other factors investigated did not show significant association with the risk of cattle raw meat contamination $(p>0.05)($ Table 5$)$. 
Table 5

Univariable logistic regression analysis of factors for contributing for isolation of Listeria species from cattle raw meat in butchers and restaurants of Ambo and Holeta towns, central Ethiopia

\begin{tabular}{|c|c|c|c|c|c|}
\hline Factor & Category & $\begin{array}{l}\text { No. } \\
\text { tested }\end{array}$ & $\begin{array}{l}\text { No. positive } \\
\text { (\%) }\end{array}$ & OR (95\% Cl) & $\begin{array}{l}\mathrm{p}- \\
\text { value }\end{array}$ \\
\hline \multirow[t]{2}{*}{ Source } & Butchers & 145 & 40 (27.59) & 1.0 & - \\
\hline & Restaurants & 145 & $42(28.97)$ & $\begin{array}{l}1.07(0.64- \\
1.78)\end{array}$ & 0.794 \\
\hline \multirow[t]{2}{*}{ Study town } & Ambo & 234 & $50(21.37)$ & 1.0 & - \\
\hline & Holeta & 58 & $32(57.14)$ & $\begin{array}{l}4.91(2.65- \\
9.07)\end{array}$ & $\begin{array}{l}\leq \\
0.001\end{array}$ \\
\hline \multirow[t]{2}{*}{ Season } & Wet & 55 & $3(5.45)$ & 1.0 & - \\
\hline & Dry & 235 & 79 (33.62) & $\begin{array}{l}8.78(2.66- \\
28.99)\end{array}$ & $\begin{array}{l}\leq \\
0.001\end{array}$ \\
\hline \multirow[t]{2}{*}{ Sex of food handlers } & Female & 145 & 40 (27.59) & 1.0 & - \\
\hline & Male & 145 & $42(28.97)$ & $\begin{array}{l}1.07(0.64- \\
1.78)\end{array}$ & 0.794 \\
\hline \multirow{3}{*}{$\begin{array}{l}\text { Age of food handlers in } \\
\text { years }\end{array}$} & $\geq 35$ & 24 & $5(20.83)$ & 1.0 & - \\
\hline & $18-24$ & 117 & $29(24.79)$ & $\begin{array}{l}1.25(0.43- \\
3.65)\end{array}$ & 0.681 \\
\hline & $25-34$ & 149 & $48(32.2)$ & $\begin{array}{l}1.81(0.64- \\
5.13)\end{array}$ & 0.267 \\
\hline \multirow[t]{2}{*}{ Marital status } & Single & 132 & $32(24.24)$ & 1.0 & - \\
\hline & Married & 158 & $50(31.65)$ & $\begin{array}{l}1.45(0.86- \\
2.43)\end{array}$ & 0.164 \\
\hline \multirow[t]{2}{*}{ Residence of origin } & Rural & 136 & $34(25)$ & 1.0 & - \\
\hline & Urban & 154 & 48 (31.17) & $\begin{array}{l}1.36(0.81- \\
2.28)\end{array}$ & 0.245 \\
\hline \multirow[t]{2}{*}{ Religion } & $\begin{array}{l}\text { Protestant and } \\
\text { others }\end{array}$ & 65 & $17(26.15)$ & 1.0 & - \\
\hline & Orthodox & 225 & 65 (28.89) & $\begin{array}{l}1.15(0.61- \\
2.14)\end{array}$ & 0.666 \\
\hline \multirow[t]{3}{*}{ Education } & illiterate & 234 & $50(21.37)$ & 1.0 & - \\
\hline & Primary school & 58 & $32(57.14)$ & $\begin{array}{l}1.02(0.38- \\
2.73)\end{array}$ & 0.974 \\
\hline & Secondary school & 14 & $4(28.57)$ & $\begin{array}{l}1.13(0.26- \\
5.01)\end{array}$ & 0.869 \\
\hline
\end{tabular}




\begin{tabular}{|c|c|c|c|c|c|}
\hline Factor & Category & $\begin{array}{l}\text { No. } \\
\text { tested }\end{array}$ & $\begin{array}{l}\text { No. positive } \\
\text { (\%) }\end{array}$ & OR (95\% Cl) & $\begin{array}{l}\mathrm{p}- \\
\text { value }\end{array}$ \\
\hline & Tertiary & 75 & $25(33.33)$ & $\begin{array}{l}1.42(0.50- \\
4,04)\end{array}$ & 0.514 \\
\hline \multirow{3}{*}{$\begin{array}{l}\text { Work experience in } \\
\text { years }\end{array}$} & $1-3$ & 166 & $46(27.71)$ & 1.0 & \\
\hline & $<1$ & 66 & 19 (28.79) & $\begin{array}{l}1.05(0.56- \\
1.98)\end{array}$ & 0.869 \\
\hline & $\geq 4$ & 58 & $17(29.31)$ & $\begin{array}{l}1.08(0.56- \\
2.09)\end{array}$ & 0.816 \\
\hline \multirow[t]{2}{*}{ Working time per day } & $\leq 8$ hours & 79 & $10(12.66)$ & 1.0 & \multirow[t]{2}{*}{0.001} \\
\hline & $\geq 9$ hours & 211 & $72(34.12)$ & $\begin{array}{l}3.57(1.74- \\
7.36)\end{array}$ & \\
\hline
\end{tabular}


Table 5

Continued...

\begin{tabular}{|c|c|c|c|c|c|}
\hline Factor & Category & $\begin{array}{l}\text { No. } \\
\text { tested }\end{array}$ & $\begin{array}{l}\text { No. positive } \\
\text { (\%) }\end{array}$ & OR $(95 \% \mathrm{Cl})$ & $\begin{array}{l}\text { p- } \\
\text { value }\end{array}$ \\
\hline \multirow{2}{*}{$\begin{array}{l}\text { Information on food hygiene \& } \\
\text { safety }\end{array}$} & No & 54 & $9(16 . .67)$ & 1.0 & - \\
\hline & Yes & 236 & $73(30.93)$ & $\begin{array}{l}2.24(1.04- \\
4.82)\end{array}$ & 0.039 \\
\hline \multirow[t]{2}{*}{ Training on food safety } & Yes & 120 & $4(20.00)$ & 1.0 & - \\
\hline & No & 270 & $78(28.89)$ & $\begin{array}{l}1.63(0.53- \\
5.01)\end{array}$ & 0.398 \\
\hline \multirow{2}{*}{$\begin{array}{l}\text { Knowledge of food hygiene and } \\
\text { safety }\end{array}$} & Yes & 179 & $48(26.82)$ & 1.0 & - \\
\hline & No & 111 & $34(30.63)$ & $\begin{array}{l}1.21(0.72- \\
2.03)\end{array}$ & 0.483 \\
\hline \multirow{2}{*}{$\begin{array}{l}\text { The practice of food hygiene } \\
\text { and safety }\end{array}$} & Yes & 122 & $33(27.05)$ & 1.0 & - \\
\hline & No & 168 & $49(29.17)$ & $\begin{array}{l}1.11(0.66- \\
1.87)\end{array}$ & 0.693 \\
\hline \multirow[t]{2}{*}{$\begin{array}{l}\text { Site of Butchers and } \\
\text { Restaurants }\end{array}$} & $\begin{array}{l}\text { Near } \\
\text { asphalt }\end{array}$ & 216 & $61(28.24)$ & 1.0 & - \\
\hline & $\begin{array}{l}\text { Gravel } \\
\text { road }\end{array}$ & 74 & $21(28.38)$ & $\begin{array}{l}1.01(0.56- \\
1.81)\end{array}$ & 0.982 \\
\hline \multirow{4}{*}{$\begin{array}{l}\text { Sanitation of Butchers and } \\
\text { Restaurants }\end{array}$} & Very good & 16 & $1(6.25)$ & 1.0 & - \\
\hline & Good & 30 & $30(29.13)$ & $\begin{array}{l}6.16(0.78- \\
48.77)\end{array}$ & 0.085 \\
\hline & Fair & 45 & $45(29.22)$ & $\begin{array}{l}6.95(0.79- \\
48.29)\end{array}$ & 0.082 \\
\hline & Poor & 6 & $6(35.29)$ & $\begin{array}{l}8.18(0.86- \\
78.05)\end{array}$ & 0.068 \\
\hline \multirow[t]{4}{*}{ Hygiene of the Slicing materials } & Very good & 16 & $1(6.25)$ & 1.0 & - \\
\hline & Good & 100 & $26(26.0)$ & $\begin{array}{l}5.27(0.66- \\
41.89)\end{array}$ & 0.116 \\
\hline & Poor & 13 & $41(30.77)$ & $\begin{array}{l}6.95(0.89- \\
54.09)\end{array}$ & 0.064 \\
\hline & Fair & 161 & $51(31.68)$ & $\begin{array}{l}6.67(0.64- \\
69.34)\end{array}$ & 0.112 \\
\hline Hygiene of the Cutting boards & Poor & 23 & $1(4.35)$ & 1.0 & - \\
\hline
\end{tabular}

13527(27.41)

$\mathrm{OR}=$ Odd Ratio, $\mathrm{Cl}=$ Confidence Interval, No. = number, prev. = prevalence 


\begin{tabular}{|c|c|c|c|c|c|}
\hline Factor & Category & $\begin{array}{l}\text { No. } \\
\text { tested }\end{array}$ & $\begin{array}{l}\text { No. positive } \\
\text { (\%) }\end{array}$ & OR $(95 \% \mathrm{Cl})$ & $\begin{array}{l}\mathrm{p}- \\
\text { value }\end{array}$ \\
\hline & Very good & 108 & 36 (33.33) & $\begin{array}{l}1.47(0.08- \\
25.32)\end{array}$ & 0.792 \\
\hline & Fair & 16 & $1(6.25)$ & $\begin{array}{l}9.56(1.25- \\
73.18)\end{array}$ & 0.030 \\
\hline & Good & 142 & $43(30.28)$ & $\begin{array}{l}11.00(1.43- \\
84.90)\end{array}$ & 0.021 \\
\hline \multirow{4}{*}{$\begin{array}{l}\text { Hygiene of the Weighing } \\
\text { balance }\end{array}$} & Poor & 19 & $2(10.53)$ & 1.0 & - \\
\hline & Very good & 30 & $6(20.00)$ & $\begin{array}{l}1.51(0.57- \\
3.99)\end{array}$ & 0.405 \\
\hline & Good & 135 & $27(27.41)$ & $\begin{array}{l}2.14(0.81- \\
5.71)\end{array}$ & 0.127 \\
\hline & Fair & 106 & 37 (34.91) & $\begin{array}{l}2.13(0.38- \\
11.83)\end{array}$ & 0.389 \\
\hline \multirow{4}{*}{$\begin{array}{l}\text { Hygiene of the Food handling } \\
\text { surfaces }\end{array}$} & Very good & 20 & $2(10.00)$ & 1.0 & - \\
\hline & Poor & 19 & $3(15.79)$ & $\begin{array}{l}1.69(0.25- \\
11.42)\end{array}$ & 0.592 \\
\hline & Fair & 135 & $40(29.63)$ & $\begin{array}{l}3.79(0.84- \\
17.10)\end{array}$ & 0.083 \\
\hline & Good & 116 & 37 (31.90) & $\begin{array}{l}4.22(0.93- \\
10.12)\end{array}$ & 0.062 \\
\hline \multirow[t]{2}{*}{ Use of refrigeration } & No & 26 & $3(11.54)$ & 1.0 & \\
\hline & Yes & 264 & 79 (29.97) & $\begin{array}{l}3.27(0.96- \\
11.22)\end{array}$ & 0.059 \\
\hline \multirow[t]{2}{*}{ Presence of insects } & No & 68 & $18(26.47)$ & 1.0 & \\
\hline & Yes & 222 & $64(28.83)$ & $\begin{array}{l}1.13(0.61- \\
2.08)\end{array}$ & 0.706 \\
\hline \multirow[t]{2}{*}{ Presence of rodents } & Yes & 77 & $21(27.270$ & 1.0 & \\
\hline & No & 213 & $61(28.64)$ & $\begin{array}{l}1.07(0.60- \\
1.92)\end{array}$ & 0.820 \\
\hline
\end{tabular}

The following variables were included in the multivariable logistic regression analysis model: study towns, season, marital status, time on work per day, information on food hygiene and safety, hygiene of food handling surfaces and use of refrigeration. All independent variables are non-collinear with each other as evidenced from the multicollinearity matrix except hygiene of the slicing material vs. sanitation 
of butchers and restaurants $[r=0.76]$, hygiene of weighing balance vs. hygiene of the slicing material $[r=$ $0.56]$ and food handling surfaces vs. hygiene of cutting boards $[r=0.63]$.These collinear variables were not entered into the multivariable model, although hygiene of the slicing material vs. sanitation of butchers and restaurants has more biological ground to explain raw meat contamination by the Listeria species. Multivariable logistic regression analysis revealed that study town and season are independent predictors of contamination of meat by Listeria species $(p<0.05)$. Information on food hygiene and safety $(p=0.054)$, and the number of hours worked per day $((p=0.079)$, though not significantly associated with the prevalence of Listeria species, they are close for association (Table 6).

Table 6

Multivariable logistic regression analysis of predictors of $L$ isteria species isolation from cattle raw meat of butchers and restaurants in Ambo and Holeta towns, Central Ethiopia.

\begin{tabular}{|c|c|c|c|}
\hline Risk factors & Category & OR $(95 \% \mathrm{Cl})$ & p-value \\
\hline \multirow[t]{2}{*}{ Study town } & Ambo & 1.0 & - \\
\hline & Holeta & $3.80(1.78-8.13)$ & $\leq 0.001$ \\
\hline \multirow[t]{2}{*}{ Season } & Wet & 1.0 & - \\
\hline & Dry & $5.41(1.56-18.78)$ & 0.008 \\
\hline \multirow[t]{2}{*}{ Marital status } & Single & 1.0 & - \\
\hline & Married & $1.49(0.81-2.74)$ & 0.195 \\
\hline \multirow[t]{2}{*}{ Working time per day } & $\leq 8$ hours & 1.0 & - \\
\hline & $\geq 9$ hours & $2.07(0.92-4.63)$ & 0.079 \\
\hline \multirow[t]{2}{*}{ Information on food hygiene \& safety } & No & 1.0 & - \\
\hline & Yes & $2.25(0.99-5.12)$ & 0.054 \\
\hline \multirow[t]{4}{*}{ Hygiene of the Food handling surfaces } & Very good & 1.0 & - \\
\hline & Poor & $1.56(0.20-12.11)$ & 0.668 \\
\hline & Fair & $1.76(0.34-9.01)$ & 0.497 \\
\hline & Good & $1.31(0.25-6.92)$ & 0.747 \\
\hline \multirow[t]{2}{*}{ Use of refrigeration } & No & 1.0 & - \\
\hline & Yes & $3.03(0.78-11.87)$ & 0.111 \\
\hline \multicolumn{4}{|c|}{$\begin{array}{l}\text { Assessment of model fitness to the observed data indicated that observed and predicted values were } \\
\text { not significantly different, i.e. the data fitted the model well (Hosmer-Lame show } X^{2}=0.76, p= \\
0.6843) \text {. The reliability of the fitted model has been further evaluated using the ROC curve }(R O C= \\
0.7296) \text {. The } 95 \% \mathrm{Cl} \text { of best-fitting variables into the model with } \mathrm{p} \leq 0.05 \text { are presented in Table } 7 \text {. }\end{array}$} \\
\hline
\end{tabular}


Table 7

Best fitting model for prediction of Listeria species isolation from cattle raw meat of butchers and restaurants in Ambo and Holeta towns, Central Ethiopia.

\begin{tabular}{|llll|}
\hline Risk factors & Category & OR $(95 \% \mathrm{Cl})$ & P-value \\
\hline Study town & Ambo & 1.0 & - \\
\cline { 2 - 4 } & Holeta & $3.47(1.84-6.54)$ & $\leq 0.001$ \\
\hline Season & Wet & 1.0 & - \\
\cline { 2 - 4 } & Dry & $5.48(1.62-18.56)$ & 0.006 \\
\hline Working time per day & $\leq 8$ hours & 1.0 & - \\
\cline { 2 - 3 } & $\geq 9$ hours & $2.32(1.08-4.96)$ & 0.030 \\
\hline OR = Odd Ratio, $\mathrm{Cl}=$ Confidence Interval, With $\mathrm{HL} \mathrm{X}^{2}=0.76, P$-value $=0.6843 \mathrm{ROC}=0.7296$. \\
\hline
\end{tabular}

\section{Antimicrobial Susceptibility}

Out of the 20 L. monocytogenes isolates subjected against 16 commercial antimicrobial discs. 16 isolates (80\%) were resistant to oxacillin; 14 (70\%) were resistant to amikacin and nalidixic acid; 12 (60\%) were resistant to chloramphenicol, 11 (55\%) were resistant to tetracycline. The $L$. monocytogenes isolates were $95 \%, 90 \%$ and $85 \%$ susceptible to amoxicillin, vancomycin, and clindamycin, respectively (Table 8 ). 
Table 8

Results of the antibiogram of $L$. monocytogenes isolates $(n=20)$ from raw cattle meat samples of the abattoirs, butchers, and restaurants

\begin{tabular}{|c|c|c|c|}
\hline \multirow{2}{*}{$\begin{array}{l}\text { Antimicrobial } \\
\text { class }\end{array}$} & \multirow{2}{*}{$\begin{array}{l}\text { Antimicrobial discs and } \\
\text { concentration }\end{array}$} & \multicolumn{2}{|c|}{ Listeria monocytogenes isolates $(n=20)$} \\
\hline & & $\begin{array}{l}\text { No. of. Susceptible } \\
\text { (\%) }\end{array}$ & $\begin{array}{l}\text { No. of. Resistant } \\
\text { (\%) }\end{array}$ \\
\hline \multirow[t]{2}{*}{ Aminoglycosides } & Amikacin $(30 \mu \mathrm{g})$ & $6(30)$ & $14(70)$ \\
\hline & Gentamicin $(10 \mu \mathrm{g})$ & $13(65)$ & $7(35)$ \\
\hline Cephem & Cefotaxime $(30 \mu \mathrm{g})$ & $5(25)$ & $15(75)$ \\
\hline Lincosamide & Clindamycin $(2 \mu \mathrm{g})$ & $17(85)$ & $3(15)$ \\
\hline Macrolide & Erythromycin $(15 \mu \mathrm{g})$ & $14(70)$ & $6(30)$ \\
\hline Phenicol & Chloramphenicol $(30 \mu \mathrm{g})$ & $8(40)$ & $12(60)$ \\
\hline Nitrofuran & Nitrofurantoin $(300 \mu \mathrm{g})$ & $19(95)$ & $1(5)$ \\
\hline \multirow[t]{2}{*}{ Quinolones } & Ciprofloxacin $(5 \mu \mathrm{g})$ & $14(70)$ & $6(30)$ \\
\hline & Nalidixic Acid $(30 \mu \mathrm{g})$ & $6(30)$ & $14(70)$ \\
\hline Sulfonamide & $\begin{array}{l}\text { Trimethoprim sulfamethoxazole } \\
(23.75 \mu \mathrm{g})\end{array}$ & $14(70)$ & $6(30)$ \\
\hline Tetracycline & Tetracycline $(30 \mu \mathrm{g})$ & $9(45)$ & $11(55)$ \\
\hline \multirow[t]{4}{*}{$\beta$-lactams } & Ampicillin $(10 \mu g)$ & $15(75)$ & $5(25)$ \\
\hline & Amoxycillin $(25 \mu \mathrm{g})$ & $19(95)$ & $1(5)$ \\
\hline & Penicillin (10 units) & $15(75)$ & $5(25)$ \\
\hline & Oxacillin $(30 \mu \mathrm{g})$ & $4(20)$ & $16(80)$ \\
\hline Glycopeptide & Vancomycin $(30 \mu \mathrm{g})$ & $18(90)$ & $2(10)$ \\
\hline
\end{tabular}

All identified Listeria monocytogenes had developed resistance to two or more classes of antimicrobial drugs. Nineteen (95\%) L. monocytogenes isolates were resistant to three or more classes of antimicrobial (multidrug resistance- MDR). One isolate (5\%) had developed resistance to ten classes of antimicrobials. The most common MDR pattern was observed against amikacin, ceftoxamine, nalidixic acid and Oxacillin. Multidrug resistance of $L$. monocytogenes isolates, number of isolates and percentages resistance as shown below (Table 9 ). 
Table 9

Antimicrobial resistance patterns of Listeria monocytogenes $(\mathrm{n}=20)$

\begin{tabular}{|c|c|c|}
\hline Antimicrobials resistance pattern & No of resistant isolates & $\%$ \\
\hline OXA-AMK & 1 & 5 \\
\hline AMP-CIP-CTR & 1 & 5 \\
\hline OXA-AMP-TET-CHL & 1 & 5 \\
\hline OXA-NAL-CLI-CTR & 1 & 5 \\
\hline XST-PEN-AMP CIP-ERY & 1 & 5 \\
\hline XST-GEN-AMK-NAL-ERY & 1 & 5 \\
\hline OXA-NAL-CIP-ERY-CTR & 1 & 5 \\
\hline OXA-AMK-CTR-TET-CHL & 1 & 5 \\
\hline XST-GEN-AMK-NAL-CTR & 1 & 5 \\
\hline XST-OXA-AMK-CTR-CHL & 1 & 5 \\
\hline OXA-AMK-NAL-CIP-CLI-CTR & 1 & 5 \\
\hline OXA-AMK-NAL-CTR-TET-CHL & 1 & 5 \\
\hline OXA-GEN-AMK-NAL-CTR-TET-CHL & 1 & 5 \\
\hline OXA-AMK-NAL-CIP-CTR-TET-CHL & 1 & 5 \\
\hline OXA-PEN-AMK-NAL-CTR-TET-CHL & 1 & 5 \\
\hline OXA-PEN-GEN-AMK-NAL-CTR-TET-CHL & 1 & 5 \\
\hline XST-OXA-GEN-NAL-ERY-CTR-TET-CHL & 1 & 5 \\
\hline OXA-PEN-GEN-AMK-NAL-ERY-CTR-TET-CHL & 1 & 5 \\
\hline XST-OXA-NIT-AMP-AMK-NAL-VAN-TET-CHL & 1 & 5 \\
\hline \multirow[t]{2}{*}{ OXA-PEN-AMX-AMP-GEN-AMK-NAL-CIP-ERY-CLI-VAN-CTR-TET-CHL } & 1 & 5 \\
\hline & 20 & 100 \\
\hline $\begin{array}{l}\text { AMK-Amikacin, AMP-Ampicillin, AMX-Amoxycillin, CIP-Ciprofloxacin, } \\
\text { Clindamycin, CTX-Cefotaxime, GEN-Gentamicin, ERY- Erythromycin } \\
\text { Nitrofurantoin OXA- Oxacillin, PEN-Penicillin, TET-Tetracycline, VAN- } \\
\text { sulfamethoxazole, }\end{array}$ & $\begin{array}{l}\text { HL-Chloramphenicol, CLI- } \\
\text { JAL-Nalidixic Acid, NIT- } \\
\text { ancomycin, XST- Trimetho }\end{array}$ & \\
\hline
\end{tabular}

\section{Discussion}




\section{Occurrence of Listeria species in raw beef from abattoir, butcher and restaurants}

In the present study, Listeria species was isolated from $28.44 \%$ of raw beef samples from abattoir, butcher, and restaurants which agrees with the reports from Addis Ababa (27.5\%) [3]. Other studies have reported significantly higher isolation rates of Listeria species in raw meat such as 95\% in Brazil [26], 81.5\% in Turkey [27], 58\% in Nigeria [28], 54.1\% in Turkey [29], 51.3\% in Ethiopia [21], and 50\% in Jordan [30].

The $4.44 \%$ isolation rate of $L$. monocytogenes in this study was comparable with the $4.1 \%$ from goat meat in Ethiopia [7] and 4.1\% in raw beef in Ethiopia [3]. However, the current finding was higher when compared to the $1.29 \%$ isolation rate from raw cow and goat meats [31], 1.6\% from minced beef [20] and $2.5 \%$ from bovine carcasses in Poland [32]. The present finding of L. monocytogenes (4.4\%) was lower when compared to the $15.6 \%$ [33] in Nordic countries, $15.4 \%$ in Bangkok [34], 25.5\% in Turkey [27]. The relatively low prevalence of $L$. monocytogenes in present study might be attributed to the difference in the study season, geographic conditions, and sample size $[35,36]$.

Meat can be contaminated by L. monocytogenes at abattoirs by cross-contamination during slaughtering, evisceration, and other processing steps. Additionally contamination and growth of Listeria at the next chain (butchers and restaurants) could occur due to poor hygienic handling and processing refrigeration; and the suitability of the meat $\mathrm{pH}$, water activity, and nutrient content [37]. The isolation rate of other Listeria species in the present study ranged from $1.78 \%-10.22 \%$. The $2.22 \%$ isolation rate of $L$. ivanovii in the present study is by far lower than the $21.9 \%$ reported by Al-Nabulsi et al [16] and $19.8 \%$ by Alsheikh, Mohammed and Abdalla [38] reported from various types of meat and meat products. However, the isolation rate of $L$. ivanovii in the present study is comparable to $2 \%$ reported from raw meat in Ethiopia [4]. The $3.77 \%$ isolation rate of the L. welshimeri in this study is in agreement with the $2.75 \%$ [16], and $4 \%$ [4] reported previously. On the other hand, the $1.78 \%$ isolation rate of $L$. seeligeri in the present study disagrees with the $27 \%$ isolation rate of $L$. seeligeri by Al-Nabulsi et al [16] but it is in line with the $1 \%$ and $2 \%$ isolation rate of $L$. seeligeri previously reported by [38] and [4], respectively. The lower occurrence of $L$ .ivanovii, L. welshimeri and $L$. seeligeri in the present study might be linked to the hygienic status of food processing environments and the differences in the bacteriological detection methods $[4,38,39]$.

Most research reports indicate that $L$. inoccua is the most common species isolated from different meat samples. For example, in Ethiopia, 83\% [3] and 19\% of L. innocua [4] have been reported. But, in this study, L. grayi $(10.22 \%)$ and L. inoccua (6.22\%) were more common than the other Listeria species. Few reports from meat samples showed that $L$. grayi was the second most abundant $L$ isteria species next to $L$. ivanovii [16]. The relatively high rate of $L$. grayi (10.22\%) and L. inoccua (6.22\%) isolation in the current study is in line with the results of Fissiha [40] in Ethiopia. The abundance of L. grayi and L. inoccua in the present study might be related to the species entrance to the processing environments via as a part of intestinal microbial flora, improper hygienic practices during processing and food handling [41, 42]. 


\section{Risk Factors Assessment}

The occurrence of Listeria species in cattle raw meat was nearly 9 times higher in the dry season when compared to the wet season. The significantly high rate isolation of Listeria species in cattle raw meat during dry season might be due to the large sample size (more than $75 \%$ of the meat samples) in the dry season and the environmental stress in cattle during the dry season that led to the shedding of the organisms in feces. It is well known that a dry climate harms the persistence of Listeria species [43]. Thus, drying is linked to water activity lowering of meat and meat products. As a consequence, the lowered moisture content of the meat enables the organism to persist in (resist) high temperature [44]. In addition, the shortage of water during dry season might impair hygienic activities of personnel and equipment in the establishments thereby increasing the chance of contamination. The isolation of Listeria species from meat in both dry and wet seasons suggests the existence of natural reservoirs of the bacteria in cattle or the environment. On the other hand, the significantly high occurrence of Listeria species in butchers and restaurants where the employees work $\geq 9$ hrs as compared to those working $\leq 8$ hrs might be related to the change in the hygienic behavior of works as they get exhausted/tired. This is the first report indicating that employees working $\geq 9$ hrs per day in handling beef are important source of beef contamination in the study areas.

In the present study, the place where the study was carried out was the predictor of Listeria species isolation ( $p \leq 0.001)$. The significantly high recovery rate of Listeria species from Holeta $(57.14 \%)$ as compared to Ambo (21.37\%) town might be related to the cool temperate climate of Holeta town favorable for the survival and multiplication of the organisms.

This study showed significant association between the risk of cattle raw meat contamination by Listeria species and information on food hygiene and safety. This finding is inconsistent with the reports of E De Booek et al [45] who suggested a significant contribution of the lack of knowledge on food hygiene and practice for high risk of contamination. In contrary to this, the results of the present study showed that less adoption of information on food hygiene and practice as a habit or culture every time during working hours by employees or workers. Thus, it may contribute to the high risk of cattle raw meat contamination by Listeria species. Moreover, the absence of law about HACCP (Hazard Analysis Critical Control Point) programs, its implementation, and the widespread inadequate hygienic practices in Ethiopia coupled with only having knowledge on food hygiene and safety without its practice or implementation might be regarded as a contributing factor for meat contamination.

Univariable logistic regression analysis also identified the hygiene of cutting boards as a risk of cattle raw meat contamination by Listeria species. This is in line with the findings of previous workers [46-48]. The types or quality, poor hygiene and absence of frequent sanitation of the cutting boards and use of unclean water for washing cutting boards might be linked to a higher chance of cutting boards being contaminated with Listeria species [48].

Antimicrobial susceptibility profile of the L. monocytogenes isolates 
The highest percentage of resistance was noted for oxacillin (75\%) followed by $55-70 \%$ resistance to amikacin, nalidixic acid, tetracycline, and chloramphenicol. The $75 \%$ resistance of oxacillin in the present study is comparable with the72.2\% resistance reported by Wieczorek [32] and [49]. While, the $70 \%$ resistance to amikacin is in contrary to the $100 \%$ susceptibility reported by Indrawattana [34]. The resistance against nalidixic acid and tetracycline in this study are in accord with the reports of Maktabi et al[35].

The $30 \%$ resistance to ciprofloxacin of this study is lower compared to the $44.4 \%$ [50] and $56 \%$ resistance [51]. The 30\% resistance to erythromycin and trimethoprim-sulfamethoxazole disagrees with $87.5 \%$ [51] and $69.4 \%$ [50] resistance. Although 35\% resistance to trimethoprim-sulfamethoxazole and gentamicin in the present study agrees with the $24 \%$ [35] and $36.1 \%$ [50] resistance, it contradicts with the $87.5 \%$ trimethoprim-sulfamethoxazole and $72.21 \%$ gentamicin resistance [51]. The $15 \%$ resistance to clindamycin is in line with the $12 \%$ resistance reported by Maktabi et al [35]. However, the $15 \%$ of cefotaxime and $25 \%$ penicillin resistance in this study is highly divergent from the $77.5 \%$ cefotaxime and $66.7 \%$ penicillin resistance reported from Ethiopia [4]. The low level of resistance (5-15\%) to amoxicillin, ceftoxamine, vancomycin and clindamycin in this study might be due to absence of usage of these drugs in veterinary medicine in Ethiopia which plausibly suggests that these antimicrobials remain an alternative regimen against the organisms $[4,52]$. While the relatively high resistance, $(\geq 30 \%)$ observed in erythromycin, chloramphenicol, trimethoprim-sulfamethoxazole, oxacillin, tetracycline, gentamycin, and trimethoprim-sulfamethoxazole might be related to the more frequent or improper usage, particularly in the public health sectors. Nevertheless, the study warrants frequent surveillance on the change in the pattern of antibiogram for this organism.

The present rate of MDR L. monocytogenes (95\%) is higher when compared to the $72.3 \%$ MDR identified from raw foods [53]. In agreement with the present study Odu and Okonko [8] also reported $L$. monocytogenes isolates that are $100 \%$ MDR. The MDR patterns of L. monocytogenes in the study towns might be due to the non-prescribed frequent and non-judicious usage of antimicrobials in livestock and public health sectors in the study towns [4]. The MDR to L. monocytogenes may occur due to plasmid or chromosomal genes transfer and mutation events in chromosomal genes from other Listeria species and Gram-positive bacteria, which may be found in foods $[53,54]$.

The high percentage of $L$. monocytogenes isolates resistant to the relatively cheaper and commonly available antimicrobials is worrisome as it might lead to the use of mandatory and more expensive drugs [4]. This is a problem for listeriosis high-risk groups in developing countries like Ethiopia because of the high cost of hospitalization and recent drug treatment leads to an economic burden on families and societies.

The isolation of L. monocytogenes from raw meat should be considered as a microbiological hazard for people since the consumption of raw or undercooked meat in the study area is a widespread food habit. The present findings have also great implications for the public health in Ethiopia because of the high 
fatality of listeriosis, the abundance of immunocompromised people and inadequate hygiene and awareness of the community.

The limitations of this study include the following: Firstly, due to the lack of resources and facilities, serotyping and molecular works on Listeria species have not been done. Secondly, antimicrobial susceptibility testing was performed only for $L$. monocytogenes. Thirdly, samples from meat handlers, equipment, and the environment were not taken to see their association. Fourthly, the questionnaire data collected from abattoir workers was not included in the logistic regression analysis due to the small number of workers $(n=33)$ who responded to our questions and the difficulty of linking responses of workers to a particular sample result as all worker handle the carcasses. This makes comparison of the results form abattoirs with that of butchers and restaurants hard.

\section{Conclusions}

The study confirmed that contamination of raw meat sold for human consumption by Listeria species is widespread in the area. Six Listeria species (Listeria monocytogenes, Listeria ivanovii, Listeria seeligeri, Listeria welshimeri, Listeria innocua and Listeria grayi) were identified. There overall occurrence of Listeria species was medium while the isolation rate of $L$. monocytogenes was relatively low. The study towns, season and working hours per day are independent predictors of Listeria species isolation. The high antimicrobials resistance and multidrug resistance among $L$. monocytogenes isolates are of great public health importance. Amoxicillin, clindamycin, nitrofurantoin, and vancomycin might be good drugs

for the treatment of $L$. monocytogenes infections in the study areas. Therefore, regular training should be given for worker in the establishments and follow up on the prudent use of antimicrobial drugs in veterinary and public health sectors are important; and subsequently, further serological and molecular studies on Listeria species are proposed.

\section{Abbreviations}

AIDS: acquired immune deficiency syndrome; CAMP: Christe, Atkins, and Munch-Peterson test; CDC: Center for disease control and prevention; CLSI: Clinical and laboratory standards institute; EC: European commission; ECDC: European Centre for Diseases Prevention and Control; ERS: Economic Research Service; EU: European Union, HACCP: Hazard Analysis and Critical Points; ISO: International Organization for Standardization; LEB: Listeria Enrichment Broth; MDR: Multi Drug-Resistant; OR: Odds Ratio; OXA: Oxford Agar; RTE: Ready-to-eat; TSYEA: Trypticase-soy yeast extract agar; UNEP: United Nations Environmental Protection.

\section{Declarations}

\section{Availability of data and materials}


The raw datasets used during the current study can be obtained upon the reasonable request of the corresponding author. The questionnaire used during the current study is available as Additional file 1.

\section{Ethics approval and consent to participate}

All study subjects were informed about the study and written informed consents were obtained from all the owners and workers of the Ambo and Holeta town butchers, restaurants and abattoirs. Confidentiality was assured by using codes. Ethical clearance was obtained from the Ambo University research and ethical review committee.

\section{Consent for publication}

Not applicable

\section{Funding}

This work was supported by Ambo University. The funder had no role in study design, data collection, and analysis, decision to publish, or preparation of the manuscript.

\section{Authors' contributions}

EZG conceived the idea, designed the project, supervised the work, analyzed and interpreted the data and drafted and approved the final manuscript for publication. GA performed the laboratory tests, participated in drafting the article and in approval of the final version for publication. BMB, EJS and HAA designed the project, supervised the work, revised the manuscript and approved the final article for publication. LMM and NDT participated in data collection, field and laboratory supervision, gave comments on the manuscript and approved the final version for publication.

\section{Acknowledgments}

The authors would like to extend their appreciation to Ambo University for financially supporting the project. We thank the workers of the study establishment for their cooperation during the interview.

\section{Declaration of interests}

The authors declare that they have no conflicts of interest.

\section{References}


1. Havelaar AH, Kirk MD, Torgerson PR, Gibb HJ, Hald T, Lake RJ, Praet N, Bellinger DC, de Silva NR, Gargouri N, et al. World Health Organization Global Estimates and Regional Comparisons of the Burden of Foodborne Disease in 2010. PLoS med. 2015;12(12):e1001923.

2. Doulgeraki Al, Ercolini D, Villani F, Nychas G. Spoilage microbiota associated to the storage of raw meat in different conditions. Int J Food Microbiol. 2012;157(2):130-41.

3. Derra FA, Karlsmose S, Monga DP, Mache A, Svendsen CA, Felix B, Granier SA, Geyid A, Taye G, Hendriksen RS. Occurrence of Listeria spp. in retail meat and dairy products in the area of Addis Ababa, Ethiopia. Foodborne Pathog Dis. 2013;10(6):577-9.

4. Garedew L, Taddese A, Biru T, Nigatu S, Kebede E, Ejo M, Fikru A, Birhanu T. Prevalence and antimicrobial susceptibility profile of listeria species from ready-to-eat foods of animal origin in Gondar Town, Ethiopia. BMC Microbiol. 2015;15:100.

5. Andargie G, Kassu A, Moges F, Tiruneh M, Huruy K. Prevalence of bacteria and intestinal parasites among food-handlers in Gondar town, northwest Ethiopia. J Health Popul Nutr. 2008;26(4):451-5.

6. CHP. Scientific Committee on Enteric Infections and Foodborne Diseases. Updated Situation of listeriosis. Center for Health Prot, 2010: 1-13.

7. Mulu S, Pal M. Studies on the prevalence, risk factors, public health implications and antibiogram of Listeria monocytogenes in sheep meat collected from municipal abattoir and butcher shops in Addis Ababa. J Foodborne Zoonotic Dis. 2016;4(1):1-14.

8. Odu NN, Okonko IO. Prevalence and Antibiotic Susceptibility of Listeria monocytogenes in Retailed Meats in Port Harcourt Metropolis, Nigeria. Public Health Res. 2017;7(4):91-9.

9. Ramaswamy V, Cresence VM, Rejitha JS, Lekshmi MU, Dharsana KS, Prasad SP, Vijila HM. Listeriareview of epidemiology and pathogenesis. J microbiol immunol infec. 2007;40(1):4-13.

10. Chiara M, Caruso M, D’Erchia AM, Manzari C, Fraccalvieri R, Goffredo E, Latorre L, Miccolupo A, Padalino I, Santagada G. Comparative genomics of Listeria sensu lato: genus-wide differences in evolutionary dynamics and the progressive gain of complex, potentially pathogenicity-related traits through lateral gene transfer. Genome Biol Evol. 2015;7(8):2154-72.

11. Cao X, Wang Y, Wang Y, Ye C. Isolation and characterization of Listeria monocytogenes from the black-headed gull feces in Kunming, China. J Infect Public health. 2018;11(1):59-63.

12. Weller D, Wiedmann M, Strawn LK. Spatial and Temporal Factors Associated with an Increased Prevalence of Listeria monocytogenes in Spinach Fields in New York State. Appl Environ Microbiol. 2015;81(17):6059-69.

13. Mazza R, Piras F, Ladu D, Putzolu M, Consolati SG, Mazzette R. Identification of Listeria Spp. Strains Isolated from Meat Products and Meat Production Plants by Multiplex Polymerase Chain Reaction. Ital J Food Saf. 2015;4(4):5498.

14. WHO. Foodborne disease outbreaks: Guidelines for investigation and control. In.: WHO Press; 2008 : 47-93.

15. Bhandare S, Sherikar AT, Paturkar AM, Waskar V, Zende R. A comparison of microbial contamination on sheep/goat carcasses in a modern Indian abattoir and traditional meat shops. Food Control. 
2007;18:854-8.

16. Al-Nabulsi AA, Osaili TM, Awad AA, Olaimat AN, Shaker RR, Holley RA. Occurrence and antibiotic susceptibility of Listeria monocytogenes isolated from raw and processed meat products in Amman, Jordan. CyTA - J Food. 2015;13(3):346-52.

17. Linda du T, Irma V. Food practices associated with increased risk of bacterial food borne disease of female students in self-catering residences at the Cape Peninsula University of Technology. J Fam Ecol Consum Sci 2005, 33.

18. Johnson JR, Murray AC, Gajewski A. Isolation and molecular characterization of nalidixic acidresistant extraintestinal pathogenic Escherichia coli from retail chicken products. Antimicrobial Agents Chemother. 2003;47:2161-8.

19. Rahimi E, Nayebpour F. Antimicrobial resistance of Escherichia coli 0157 . H7 isolated from feaces of ruminant animals in Iran. J Cell Animal Biol. 2012;6:104-8.

20. Molla B, Yilma R, Alemayehu D. Listeria monocytogenes and other Listeria species in retail meat and milk products in Addis Ababa, Ethiopia. Ethiop J Health Dev. 2004;18(3):208-12.

21. Gebretsadik S, Kassa T, Alemayehu H, Huruy K, Kebede N. Isolation and characterization of Listeria monocytogenes and other Listeria species in foods of animal origin in Addis Ababa, Ethiopia. $\mathrm{J}$ Infect Public Health. 2011;4(1):22-9.

22. CSA. Population and Housing Census of Ethiopia. In.; 2007.

23. Thrusfield M: Describing disease occurrence. Veterinary epidemiology 3rd edition Blackwell Publishing 2007:46-74.

24. ISO:. Microbiology of food and animal feeding stuffs Horizontal method for the detection and enumeration of Listeria monocytogenes, Part 1: Detection method. Switzerland: In. Geneva; 2004.

25. CLSI. Clinical and laboratory standards institute. Performance for antimicrobial disk susceptibility testing. 950 west valley road, suite 2500, Wayne, Pennsylvania 19087 USA, 2017.

26. Destro MT, de Melo Serrano A, Kabuki DY. Isolation of Listeria species from some Brazilian meat and dairy products. Food Control. 1991;2(2):110-2.

27. Arslan S, Baytur S. Prevalence and antimicrobial resistance of Listeria species and subtyping and virulence factors of Listeria monocytogenes from retail meat. $J$ food saf. 2019;39(1):e12578.

28. Oyelami L, O Aboaba O, Banjo A. O: Prevalence and antibiotics susceptibility profile of Listeria monocytogenes isolated from processed and unprocessed meat products. Food Microbiol Sci, 2018.

29. Yücel N, Çıtak S, Önder M. Prevalence and antibiotic resistance of Listeria species in meat products in Ankara, Turkey. Food Microbiol. 2005;22(2):241-5.

30. Osaili TM, Alaboudi AR, Nesiar EA. Prevalence of Listeria spp. and antibiotic susceptibility of Listeria monocytogenes isolated from raw chicken and ready-to-eat chicken products in Jordan. Food Control. 2011;22(3):586-90.

31. Eruteya 0 , Odunfa S, Lahor J. Listeria spp. in raw cow and goat meat in port harcourt, Nigeria. British Biotechnol J. 2014;4:204-14. 
32. Wieczorek K, Dmowska K, Osek J. Prevalence, characterization, and antimicrobial resistance of Listeria monocytogenes isolates from bovine hides and carcasses. Appl Environ Microbiol. 2012;78(6):2043-5.

33. Gudbjörnsdóttir B, Suihko ML, Gustavsson P, Thorkelsson G, Salo S, Sjöberg AM, Niclasen O, Bredholt $\mathrm{S}$. The incidence of Listeria monocytogenes in meat, poultry and seafood plants in the Nordic countries. Food Microbiol. 2004;21(2):217-25.

34. Indrawattana N, Nibaddhasobon T, Sookrung N, Chongsa-Nguan M, Tungtrongchitr A, Makino S, Tungyong W, Chaicumpa W. Prevalence of Listeria monocytogenes in raw meats marketed in Bangkok and characterization of the isolates by phenotypic and molecular methods. J Health Popul Nutr. 2011;29(1):26-38.

35. Maktabi S, Pourmehdi M, Zarei M, Fooladgar AA. Detection of Antibiotic Resistant Listeria spp. in Beef Burgers Distributed in Ahvaz City, Iran. Jundishapur J Health Sci 2016, 8(2).

36. Marian M, Aminah SS, Zuraini M, Son R, Maimunah M, Lee H, Wong W, Elexson N. MPN-PCR detection and antimicrobial resistance of Listeria monocytogenes isolated from raw and ready-to-eat foods in Malaysia. Food Control. 2012;28(2):309-14.

37. Vitas A. Occurrence of Listeria monocytogenes in fresh and processed foods in Navarra (Spain). Int J Food Microbiol. 2004;90(3):349-56.

38. Alsheikh A, Mohammed G, Abdalla M. First Isolation and Identification of Listeria monocytogenes from Fresh Raw Dressed Broiler Chicken in Sudan. Res J Microbiol. 2012;7(6):319-26.

39. Awaisheh S. Incidence and contamination level of Listeria monocytogenes and other Listeria spp. in ready-to-eat meat products in Jordan. J food protection. 2010;73(3):535-40.

40. Fisseha S. The occurrence of Listeria monocytogenes in ready-to-eat foods of animal origin and its antibiotic susceptibility profile, Bishoftu and Dukem Towns, Central Ethiopia. World J Adv Healthcare Res. 2017;1(2):47-62.

41. Fenlon D, Wilson J, Donachie W. The incidence and level of Listeria monocytogenes contamination of food sources at primary production and initial processing. J App Bacteriol. 1996;81(6):641-50.

42. Gibbons I-s, Adesiyun A, Seepersadsingh N, Rahaman S. Investigation for possible source (s) of contamination of ready-to-eat meat products with Listeria spp. and other pathogens in a meat processing plant in Trinidad. Food Microbiol. 2006;23(4):359-66.

43. Eslami G, Samadi R, Taherpanah R, Taherpor A, Baseri N. Detection of actA and InIB genes in Listeria monocytogenes Isolated from women with Spontaneous abortions. Novel Biomed. 2014;2(1):18-21.

44. Sörqvist S. Heat resistance of different serovars of Listeria monocytogenes. J app bacteriol. $1994 ; 76(4): 383-8$.

45. De Boeck E, Jacxsens L, Bollaerts M, Uyttendaele M, Vlerick P. Interplay between food safety climate, food safety management system and microbiological hygiene in farm butcheries and affiliated butcher shops. Food control. 2016;65:78-91.

46. Jianu C, Chiş C. Study on the hygiene knowledge of food handlers working in small and mediumsized companies in western Romania. Food Control. 2012;26(1):151-6. 
47. Hori K, Matsumoto S. Bacterial adhesion: from mechanism to control. Biochem Eng J. 2010;48(3):424-34.

48. Ismaïl R, Aviat F, Michel V, Le Bayon I, Gay-Perret P, Kutnik M, Fédérighi M. Methods for recovering microorganisms from solid surfaces used in the food industry: a review of the literature. Int $J$ Environ Res public health. 2013;10(11):6169-83.

49. Gomez D, Azon E, Marco N, Carraminana JJ, Rota C, Arino A, Yanguela J. Antimicrobial resistance of Listeria monocytogenes and Listeria innocua from meat products and meat-processing environment. Food Microbiol. 2014;42:61-5.

50. Usman U, Kwaga J, Kabir J, Olonitola O. Isolation and antimicrobial susceptability of Listeria monocytogenes from raw milk and milk products in Northern Kaduna State, Nigeria. J Appl Environ Microbiol. 2016;4(3):46-54.

51. Ishola OO, Mosugu JI, Adesokan HK. Prevalence and antibiotic susceptibility profiles of Listeria monocytogenes contamination of chicken flocks and meat in Oyo State, south-western Nigeria: Public health implications. J Prev Med Hyg. 2016;57(3):E157-63.

52. Abera F: Prevalence and antimicrobial profile of Listeria monocytogenes in retail meat and dairy products in Addis Ababa and its surrounding towns, Ethiopia. Addis Abeba University; 2007.

53. Wang G, Qian W, Zhang X, Wang H, Ye K, Bai Y, Zhou G. Prevalence, genetic diversity and antimicrobial resistance of Listeria monocytogenes isolated from ready-to-eat meat products in Nanjing, China. Food Control. 2015;50:202-8.

54. Harakeh S, Saleh I, Zouhairi O, Baydoun E, Barbour E, Alwan N. Antimicrobial resistance of Listeria monocytogenes isolated from dairy-based food products. SciTotal Environ. 2009;407(13):4022-7.

\section{Supplementary Files}

This is a list of supplementary files associated with this preprint. Click to download.

- Additionalfile1.questionnaire.docx

- Additionalfile2.RAWDATA.xlsx

- Additionalfile3AMRoflisteria.xIsx 